\title{
Gene Transfer in Strains of Pasteurella pseudotuberculosis
}

\author{
By W. D. LAWTON \\ Biological Sciences Laboratory, Fort Detrick, Frederick, Maryland, U.S.A. \\ B. C. MORRIS AND T. W. BURROWS \\ Microbiological Research Establishment, Porton Down, Salisbury, Wilts.
}

(Accepted for publication 15 November 1967)

\begin{abstract}
SUMMARY
Pasteurella pseudotuberculosis strain 32IV accepted the $\mathrm{F}^{\prime}$ lac episome from Escherichia coli strain 23.10s and behaved as a gene donor in crosses with several different auxotrophs of $P$. pseudotuberculosis. Some selected donor markers were transferred at frequencies of $10^{-4}-\mathrm{IO}^{-5}$ per donor cell while others appeared not to be transferred. Up to $40 \%$ of recombinants were Lac + . Selected recombinants showed differing unselected marker frequencies with differing selected markers; those obtained by using double marker selection showed increased unselected marker frequencies. Some alternative explanations for the origin of recombinants (syntrophic growth, mixed clones, multiple recipient reversions) were not supported by experiment.
\end{abstract}

\section{INTRODUCTION}

Previous attempts to discover a gene transfer system in Pasteurella pestis involving conjugation, transduction or transformation were unsuccessful (Burrows, 1962). The report by Martin \& Jacob (I962) that an avirulent strain of $P$. pestis could accept the $F^{\prime}$ lac episome from Escherichia coli and observations at the Microbiological Research Establishment that strains of $P$. pseudotuberculosis could accept R-factors (J. Boyle, unpublished) stimulated efforts to obtain episome-mediated gene transfer in Pasteurella. Although our ultimate interest is in the genetics of $P$. pestis we are approaching this subject through the very closely related but more easily handled organism P.pseudotuberculosis and have studied the transfer of markers from an $F^{\prime}$ lac infected donor strain to different recipient strains of this latter species. To avoid tedious repetition of non-committal terms such as 'presumed donor', 'presumed recombinant' in this first report, we use the terminology currently employed by others in their descriptions of the firmly established fertility system of E. coli and assume its applicability to the system here described for Pasteurella. In this paper we present evidence from which we deduce the occurrence of gene transfer and show that other explanations for the development of 'recombinant' strains are less acceptable.

\section{METHODS}

Strains. Escherichia coli $\mathrm{K} \mathrm{I} 2$ strain 23.IOS Met-(F'lac) was kindly supplied by Dr R. C. Clowes. Pasteurella pseudotuberculosis strain $32 \mathrm{IV}$ was obtained from Professor E. Thal, Stockholm, in 1958 and held since at the Microbiological Research Establishment under the number MRE259. Auxotrophic derivatives of strain MRE259 
were derived by presumed single-step mutations following treatment with nitrous acid (Kaudewitz, I959). Derivatives resistant to P.pseudotuberculosis phage IV were isolated as colonies arising on lawns of sensitive bacteria lysed by phage. Streptomycinresistant strains were isolated from sensitive parent bacteria by plating on complete medium supplemented with streptomycin to $100 \mu \mathrm{g} . / \mathrm{ml}$. Strains were stored in vacuo at $2^{\circ}$ as dried gelatin pellets (Stamp, 1947). Abbreviations designating genotypes and phenotypes of strains follow the recommendations of Demerec, Adelberg, Clark \& Hartman (1966) with the additional symbols.

$p_{4} s=$ locus determining sensitivity to phage IV (phenotype symbols $\mathrm{P}_{4} \mathrm{~S}$ and $\mathrm{P}_{4} \mathrm{R}$ for sensitivity and resistance respectively).

$p t h=$ Locus determining the presumed single-step mutation leading to a double requirement for any purine + thiamine (phenotype symbols Pth + and Pth for independence and dependence on these factors respectively).

The relevant genotypes of the strains used are shown in the tables.

Media. Tryptic digest of meat broth (TMB) or agar (TMA) and blood agar base (BAB) no. 2 (Oxo Limited) were used as complete media. Minimal agar medium (MA) was prepared as follows. Solution A (g./1. distilled water): Agar (Oxoid no. 3), 30; sodium citrate $2 \mathrm{H}_{2} \mathrm{O}, \mathrm{I}$; autoclaved $\mathrm{I} 15^{\circ}$ for $\mathrm{I} 5 \mathrm{~min}$.; solution $\mathrm{B}$ (g./l. distilled water) $\mathrm{K}_{2} \mathrm{HPO}_{4}, 2 \mathrm{I} ; \mathrm{KH}_{2} \mathrm{PO}_{4}, 9 ;\left(\mathrm{NH}_{4}\right)_{2} \mathrm{SO}_{4}, 2$; sodium citrate $2 \mathrm{H}_{2} \mathrm{O}, \mathrm{I} ; \mathrm{MgSO}_{4} \cdot 7 \mathrm{H}_{2} \mathrm{O}$, O. I ; adjusted to $\mathrm{pH} 7 \cdot 2$ and autoclaved similarly. The final medium contained equal volumes of solutions $\mathrm{A}$ and $\mathrm{B}+$ glucose (sterilized by filtration) to give $0.2 \%(\mathrm{w} / \mathrm{v})$.

Minimal salts solution (MS) was solution $\mathrm{B}+$ an equal volume of distilled water. Selective media were MA variously supplemented, as required, with growth factors to give the concentrations (mM): arginine, 0.5 ; cysteine, 0.4 ; glycine, I; histidine, 0.2 ; isoleucine, 0.5 ; methionine, 0.2 ; phenylalanine, 0.5 ; serine, $\mathrm{I}$; threonine, $\mathrm{I}$; tryptophan, $0 . \mathrm{I}$; tyrosine, 0.5 ; purine, 0.05 ; thiamine, $0.00 \mathrm{I}$.

Lactose indicator medium was BAB medium +lactose $\mathrm{I} \%(\mathrm{w} / \mathrm{v})$, bromothymol blue $0.0025 \%(\mathrm{w} / \mathrm{v})$ and triphenyltetrazolium chloride $0.005 \%(\mathrm{w} / \mathrm{v})$. On this medium $\mathrm{Lac}+$ colonies were yellow and Lac- colonies reddish purple.

Crossing procedure. The strain MRE 2027 was used as donor throughout. It had the relevant genotype cys-5 pth-2 p4s str-II ( $\mathrm{F}^{\prime}$ lac). Donor bacteria were grown in $10 \mathrm{ml}$. TMB medium + lactose $(0 . \mathrm{I} \%, \mathrm{~W} / \mathrm{v})$ at $28^{\circ}$ with rotation. After $\mathrm{I} 8 \mathrm{hr}$ incubation $5 \mathrm{ml}$. of the culture was added to $5 \mathrm{ml}$. of fresh medium and incubated, with rotation, for a further $2 \mathrm{hr}$. The exponentially growing bacteria were centrifuged and resuspended in $\mathrm{I} 0 \mathrm{ml}$. of MS. Five $\mathrm{ml}$. of this suspension (containing about $\mathrm{I} \times \mathrm{IO}^{9}$ organisms/ ml.) were exposed, with gentle agitation in a Petri dish, to a $15 \mathrm{~W}$. ultraviolet lamp (Hanovia Limited) at a distance of $36 \mathrm{~cm}$. for $30 \mathrm{sec}$. and then diluted ro-fold in MS to provide the donor bacteria suspension.

The various recipient strains were grown on TMA at $28^{\circ}$ for $20 \mathrm{hr}$. They were then suspended in TMB to give concentrations of about $5 \times 10^{9}$ organisms $/ \mathrm{ml}$. to provide the recipient bacteria suspensions.

One-tenth $\mathrm{ml}$. of recipient suspension was spread over the appropriate selective media plates followed by the same volume of donor suspension spread over the recipient lawns. Control plates spread with recipient suspension alone and with donor suspension alone were included in every experiment. All plates were incubated at $28^{\circ}$ and scored for recombinants after 4-6 days. 
Purification and analysis of recombinants. Colonies appearing on the different selective media were streaked on plates of the same media on which they had arisen and single colonies from these streaks were restreaked as before. Single colonies, one from each of the final growths, were inoculated to marked positions on plates of the same medium to provide master plates from which colonies could be replicated to variously supplemented media (by using a 76-needle replicator) to score for unselected markers. The purified recombinants always were replicated to donor selective medium to ensure their freedom from contaminating donor bacteria whose presence would have made unselected marker analysis suspect. In later experiments it was found adequate to replicate recombinant colonies 3 times on selective agar (without streaking and picking single colonies) to ensure their freedom from contamination by parent bacteria.

Recombinants were scored for phage sensitivity by replicating to BAB overlayered with $3 \mathrm{ml}$. soft agar containing $\mathrm{I} \times 10^{8}$ p.f.u. of phage IV per $\mathrm{ml}$. and for streptomycin resistance by replicating to $\mathrm{BAB}+$ streptomycin, $100 \mu \mathrm{g} . / \mathrm{ml}$.

\section{RESULTS}

\section{Isolation of donor strain MRE 2027}

From the Pasteurella pseudotuberculosis strain MRE 259 we derived the Cys - strain MRE3I 2 and from this the SmR strain MRE2077. This was grown in broth culture with Escherichia coli 23. IOS and plated on minimal agar containing cysteine, lactose (in place of glucose) and streptomycin. Colonies arising on this medium were indistinguishable from strain MRE 2077 except for being Lac + . Representative colonies transferred lac to other strains of P. pseudotuberculosis, to P. pestis and to E. coli, and were presumed therefore to have acquired the transmissible element $F^{\prime}$ lac. One such representative, MRE 2007, was used as parent strain for the production of a series. of auxotrophs, one of which had the double requirement for purine + thiamine and appeared to be the most efficient gene donor of a number tested in crosses with other, Lac-, auxotrophs. This Pth - derivative was chosen for further study and numbered MRE 2027. Donor suspensions prepared for use in crosses usually contained about $2 \%$ Lac - bacteria.

\section{Gene transfer}

The crossing technique described under Methods was developed after considerable experience. Crosses made under conditions effective for Escherichia coli, i.e. mating in broth at $37^{\circ}$ followed by dilution and plating on selective media, were sterile. It seemed that the growth conditions and treatment of the donor suspension were particularly critical. Ultraviolet irradiation of donor bacteria decreased viability to about $50 \%$ but increased the yield of recombinants 5 - to Io-fold (i.e. a 10- to 20-fold increase per viable donor bacterium) above that of un-irradiated cells. When following. ultra-violet irradiation the donor bacteria were incubated for $\mathrm{I} \mathrm{hr}$ in TMB at $28^{\circ}$ before crossing (Hayes, I953) a further increase (about $1 \cdot 5$-fold) in yield sometimes occurred. This additional treatment, however, seemed to be an unwarranted modification of the technique for routine use.

Minimal enrichment of the selective media on which crosses were performed was necessary for fertility. Thus, when donor and recipient mixtures were incubated in TMB or in MS for $5 \mathrm{hr}$ at $28^{\circ}$, the bacteria deposited, washed, resuspended in MS and plated on selective medium, no recombinants were obtained. The same washed 
suspensions plated on selective medium enriched with $0 . \mathrm{I} \mathrm{ml}$. TMB per plate yielded recombinants. Enrichment with 0.1 $\mathrm{ml}$. TMB appeared to be optimal for maximum fertility with minimum background growth and was conveniently made by using recipient cells suspended in TMB.

Table I. Fertility of an $F^{\prime}$ lac donor and infertility of its Lac- segregant in crosses with different recipient strains of Pasteurella pseudotuberculosis

Donor: MRE 2027: cys-5 pth-2 str-II (F'lac).

\begin{tabular}{|c|c|c|c|c|c|c|c|}
\hline \multirow{3}{*}{\multicolumn{2}{|c|}{ Recipient strain }} & \multirow{4}{*}{$\begin{array}{c}\text { Selected } \\
\text { phenotype }\end{array}$} & \multicolumn{5}{|c|}{ Numbers of colonies on selective media* } \\
\hline & & & \multicolumn{2}{|c|}{ Crosses } & \multicolumn{3}{|c|}{ Controls } \\
\hline & & & \multirow{2}{*}{$\begin{array}{l}\mathrm{F}^{\prime} l a c \\
\text { donor }\end{array}$} & \multirow{2}{*}{$\begin{array}{l}\text { Lac- } \\
\text { donor }\end{array}$} & \multirow{2}{*}{$\begin{array}{l}\text { Recipient } \\
\text { alone }\end{array}$} & \multirow{2}{*}{$\begin{array}{l}F^{\prime} l a c \\
\text { donor } \\
\text { alone }\end{array}$} & \multirow{2}{*}{$\begin{array}{l}\text { Lac- } \\
\text { donor } \\
\text { alone }\end{array}$} \\
\hline No. & genotype & & & & & & \\
\hline MRE 2024 & leu-I gly-2 ser-I & Leu + & 335 & 0 & 0 & o & 0 \\
\hline MRE 2056 & tyr-I his-I3 & $\begin{array}{l}\text { Tyr }+ \\
\text { His }+\end{array}$ & $\begin{array}{r}200 \\
20\end{array}$ & $\begin{array}{l}5 \\
0\end{array}$ & $\begin{array}{l}5 \\
0\end{array}$ & $\begin{array}{l}0 \\
0\end{array}$ & $\begin{array}{l}0 \\
0\end{array}$ \\
\hline MRE 2118 & met-5 arg-8 & $\begin{array}{l}\text { Met }+ \\
\text { Arg + }\end{array}$ & $\begin{array}{r}0 \\
112\end{array}$ & $\begin{array}{l}0 \\
4\end{array}$ & $\begin{array}{l}0 \\
8\end{array}$ & $\begin{array}{l}0 \\
0\end{array}$ & $\begin{array}{l}0 \\
0\end{array}$ \\
\hline MRE 2 I I 7 & met-5 leu-3 & $\begin{array}{l}\text { Met+ } \\
\text { Leu + }\end{array}$ & $\begin{array}{r}0 \\
320\end{array}$ & $\begin{array}{l}0 \\
0\end{array}$ & $\begin{array}{l}\text { o } \\
\text { I }\end{array}$ & $\begin{array}{l}0 \\
0\end{array}$ & $\begin{array}{l}0 \\
0\end{array}$ \\
\hline
\end{tabular}

* The different selective media were MA plus all growth factors of the particular recipient strain except that for which selection for independence was being made.

Table 2. Occurrence of unselected donor markers in recombinants from crosses between strains of Pasteurella pseudotuberculosis

Donor: MRE 2027: cys-5 pth-2-str-II ( $\left.\mathrm{F}^{\prime} l a c\right)$

\begin{tabular}{|c|c|c|c|c|c|c|c|c|}
\hline \multicolumn{2}{|c|}{ Recipient } & \multirow[b]{2}{*}{$\begin{array}{c}\text { Expt } \\
\text { no. }\end{array}$} & \multirow[b]{2}{*}{$\begin{array}{c}\text { Selected } \\
\text { phenotype }\end{array}$} & \multirow[b]{2}{*}{$\begin{array}{l}\text { Number } \\
\text { analysed }\end{array}$} & \multicolumn{4}{|c|}{$\begin{array}{l}\text { Unselected donor markers* } \\
(\%)\end{array}$} \\
\hline $\begin{array}{c}\text { Strain } \\
\text { no. }\end{array}$ & $\begin{array}{l}\text { Relevant } \\
\text { genotype }\end{array}$ & & & & lac & $p 4 s$ & met & Others \\
\hline MRE 2056 & tyr-I his-I 3 & $\begin{array}{l}\text { I } \\
2\end{array}$ & $\begin{array}{l}\text { Tyr+ } \\
\text { His }+\end{array}$ & $\begin{array}{l}98 \\
27\end{array}$ & $\begin{array}{r}25 \\
4\end{array}$ & $\dot{.}$ & $\dot{.}$ & $\begin{array}{l}\text { his } 0 \\
\text { tyr } 0\end{array}$ \\
\hline MRE 2 I I 7 & met-5 leu-3 & 3 & Leu+ & 69 & 20 & . & o & . \\
\hline MRE 2205 & $\begin{array}{l}\text { met }-5 \text { arg-8 } \\
\text { p4 -2 }\end{array}$ & 4 & Arg + & 49 & I8 & 37 & 0 & $\cdot$ \\
\hline MRE $225^{8}$ & $\begin{array}{l}\text { met }-5 \text { arg- } 8 \\
\text { ile-3 p } 4 r-2\end{array}$ & $\begin{array}{l}5 \\
6\end{array}$ & $\begin{array}{l}\text { Arg+ } \\
\text { Ile + } \\
\text { Arg+ } \\
\text { Ile + }\end{array}$ & $\begin{array}{r}67 \\
68 \\
225 \\
304\end{array}$ & $\begin{array}{l}24 \\
22 \\
17 \\
18\end{array}$ & $\begin{array}{r}36 \\
6 \\
25 \\
4\end{array}$ & $\begin{array}{l}0 \\
0 \\
0 \\
0\end{array}$ & $\begin{array}{l}\text { ile } 5 \\
\text { arg } 16 \\
\text { ile } 2 \\
\text { arg } 3\end{array}$ \\
\hline MRE 2263 & $\begin{array}{l}\text { met }-5 \text { arg- } 8 \\
\text { aro-2 p4r-2 }\end{array}$ & 7 & $\begin{array}{l}\text { Arg }+ \\
\text { Aro }+\end{array}$ & $\begin{array}{l}376 \\
300\end{array}$ & $\begin{array}{l}14 \\
25\end{array}$ & $\begin{array}{r}36 \\
9\end{array}$ & $\begin{array}{r}\mathrm{I} \\
\mathrm{I} 8\end{array}$ & $\begin{array}{l}\operatorname{aro} 3 \\
\arg 14\end{array}$ \\
\hline MRE 2256 & $\begin{array}{l}\text { met }-5 \text { arg- } 8 \\
\text { his }-8 \text { p } 4 r-2\end{array}$ & $\begin{array}{l}8 \\
9\end{array}$ & $\begin{array}{l}\text { Arg+ } \\
\text { Arg+ }\end{array}$ & $\begin{array}{l}138 \\
304\end{array}$ & $\begin{array}{l}28 \\
22\end{array}$ & $\begin{array}{l}37 \\
35\end{array}$ & $\begin{array}{l}0 \\
0\end{array}$ & $\begin{array}{l}\text { his } 81 \\
\text { his } 85\end{array}$ \\
\hline MRE 229I & $\begin{array}{l}\text { met }-5 \text { arg-8 } \\
\text { his-8 trp-3 } \\
\text { p4r-2 }\end{array}$ & Io & $\operatorname{Arg}+$ & 225 & 20 & 32 & 0 & $\begin{array}{l}\text { his } 85 \\
\text { trp } 4\end{array}$ \\
\hline & & & $\operatorname{Trp}+$ & 225 & 29 & 47 & I & $\begin{array}{l}\text { his } 43 \\
\arg 36\end{array}$ \\
\hline & & & $\begin{array}{l}\text { Arg }+ \\
\text { Trp }+\end{array}$ & 225 & 40 & 76 & 2 & his 95 \\
\hline
\end{tabular}

* No recombinants showed the donor phenotype SmR. 
Table I summarizes the results of crosses involving four differently marked recipient strains. The recovery of many colonies per plate in the crosses in contrast to the small numbers on control plates indicated that the donor markers arg, leu, his and tyr were transferred to the different recipients at frequencies ranging from about $1 \mathrm{O}^{-4}$ to $\mathrm{IO}^{-5}$ per donor bacterium. There was no indication of fertility when the donor was crossed with auxotrophs having requirements for methionine, nicotinamide, thiamin or uracil, nor when the donor strain was replaced by one of its Lac- spontaneous segregants.

From the Met - Arg - strain MRE 2 I I 8 (Table I) additionally marked strains were derived to test double marker selection and to permit unselected marker analysis of recombinants. As shown in Table 2 the markers arg, ile, aro and trp were transferred both as selected and as unselected markers and his, $p 4 s$ and met as unselected markers. The donor marker str was not observed in recombinants in these experiments. Recombinants were obtained with double selection for the markers arg and trp; these showed increased unselected marker frequencies for his and for $p 4 s$ when compared with recombinants obtained with single selection for arg or for trp.

\section{Alternatives to gene transfer}

Mechanisms other than gene transfer seemed unlikely to have been responsible for the development of colonies on selective media and for these colonies to have possessed unselected donor properties. Nevertheless, some other possibilities were examined. To explain the development of larger numbers of colonies from mixed parent platings than from parent control platings it could be argued that syntrophism, between the parental strains, permitted larger populations of recipient cells and consequently larger numbers of reversions. If this explanation held one would expect that following the plating of an Arg - recipient strain on arg selective media to which was added increasing concentrations of arginine, increasing numbers of revertants would arise to equal, or exceed, the numbers of recombinants in crosses with this recipient. The recipient strain MRE2205 (Table 2) tested in this way showed a maximum of 14 colonies from reversions of the $\arg -8$ locus (Table 3 ) in contrast to more than roo recombinants/plate in crosses. A visual comparison of the background growth from mixed parent platings with those on arginine supplemented medium in these experiments indicated that the former did not exceed $\mathrm{I} \cdot 2 \times 10^{9}$ bacteria per plate. A total of $76 \mathrm{Arg}+$ revertants derived from these experiments were tested for unselected markers as if they had been Arg + recombinants. None scored $\mathrm{P}, 4 \mathrm{~S}$ or Lac + in contrast to recombinants selected for Arg+, of which about $30 \%$ were $\mathrm{P}_{4} \mathrm{~S}$ and about $20 \%$ were $\mathrm{Lac}+$. The donor strain plated on minimal medium with increasing specific growth factor additions showed no double reversions. With this strain full supplementation with purine + thiamine allowed the detection of rare Cys + revertants but no reversions to Pth + were seen on plates fully supplemented with cysteine.

As a further test to exclude syntrophism a membrane filter was interposed between donor and recipient bacteria on selective media. These experiments resembled those of Dushman (1963) who showed that syntrophism could account for the apparent fertility of auxotrophic strains of Serratia marcescens. Our results (Table 4), in contrast to those reported with Serratia, showed that the number of colonies arising when parent bacteria were separated was less than $5 \%$ of that obtained when free contact of parent bacteria was permitted. Colonies arising on areas covered by membranes mostly 
were restricted to the margins of the membranes where separation of parental bacteria may not have been complete. Further (Table 4), when parent bacteria were applied to selective media plates in separate, thin $(0.3 \mathrm{~mm}$.) agar layers, virtually no colonies developed whether or not the agar layers were separated by a membrane. However, when parent suspensions were mixed before adding to melted agar so that both parents were contained within the same agar layer, many colonies developed.

In an additional test of syntrophism confluent lawns of donor and of recipient cells (MRE2256) grown on separate BAB plates were replicated with the same 76-point replicator to another $\mathrm{BAB}$ plate which was incubated at $28^{\circ}$ for $\mathrm{I} 8 \mathrm{hr}$. This master plate, known to carry mixed clones, was replicated to the differently supplemented

Table 3. Populations and numbers of spontaneous Arg + revertants of Pasteurella pseudotuberculosis strain MRE2205 plated on Arg + selective medium increasingly supplemented with arginine

Strain MRE 2205, Met - Arg - P4R, was grown and suspended in TMB as for use as a recipient in crosses and $0.1 \mathrm{ml}$. volumes $\left(c .5 \times 10^{8}\right.$ organisms) spread on MA plus methionine plates containing increasing additions of arginine. One-tenth $\mathrm{ml}$. of MS was then spread on the plates (to simulate application of donor cells) and the plates incubated for 5 days at $28^{\circ}$. Macroscopically obvious colonies were counted, removed from the agar, the remaining background population suspended in MS and measured turbidimetrically.

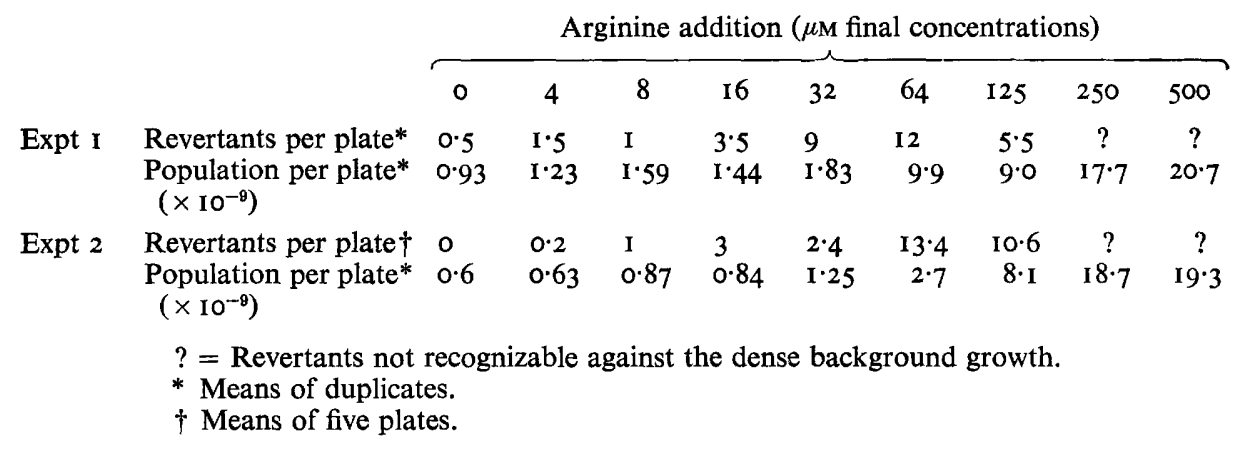

minimal media used in the analyses of recombinants. Two parallel series of plates were replicated with the donor alone and with the recipient alone and all plates incubated at $28^{\circ}$ for 5 days. All separate donor and recipient replicates scored correctly. Mixed replicates grew both on minimal medium selective for the donor and on that selective for the recipient and all scored $\mathrm{P}_{4} \mathrm{R}$ and $\mathrm{SmR}$ on complete medium. On lactose indicator medium they produced brownish colonies. No growths were visible on the differently supplemented minimal media which would have been selective for syntrophic growths, reversions or for recombinants. The same results were obtained with the recipient strains MRE 2258 and MRE 2263. From the above experiments we obtained no support for the possibility that syntrophism followed by reversions could account for the fertility we had inferred. Further, the experiments excluded the possibility that recombinants falsely showed donor markers through contamination with donor cells since, unlike mixed clones, no recombinants grew on donor specific medium, none were SmR and several were $\mathrm{P}_{4} \mathrm{~S}$. 
Table 4. Reduction of the fertility of Pasteurella pseudotuberculosis crosses by interposing a membrane between parent bacteria or by separating them in different agar layers

Suspensions of parent bacteria were prepared as for use in crosses. Donor, or recipient, bacteria were first applied to selective agar plates either by spreading $0.1 \mathrm{ml}$. of suspension or by adding this to $2 \mathrm{ml}$. of selective agar at $45^{\circ}$ and overlayering the mixture. A semicircular membrane filter (standard grade, Oxo Limited, London) was then applied to cover one half of the agar surface, followed by the addition of recipient, or donor, bacteria as previously. The plates were incubated at $28^{\circ}$ for 5 days and the colonies counted. The donor strain MRE 2027 was used throughout.

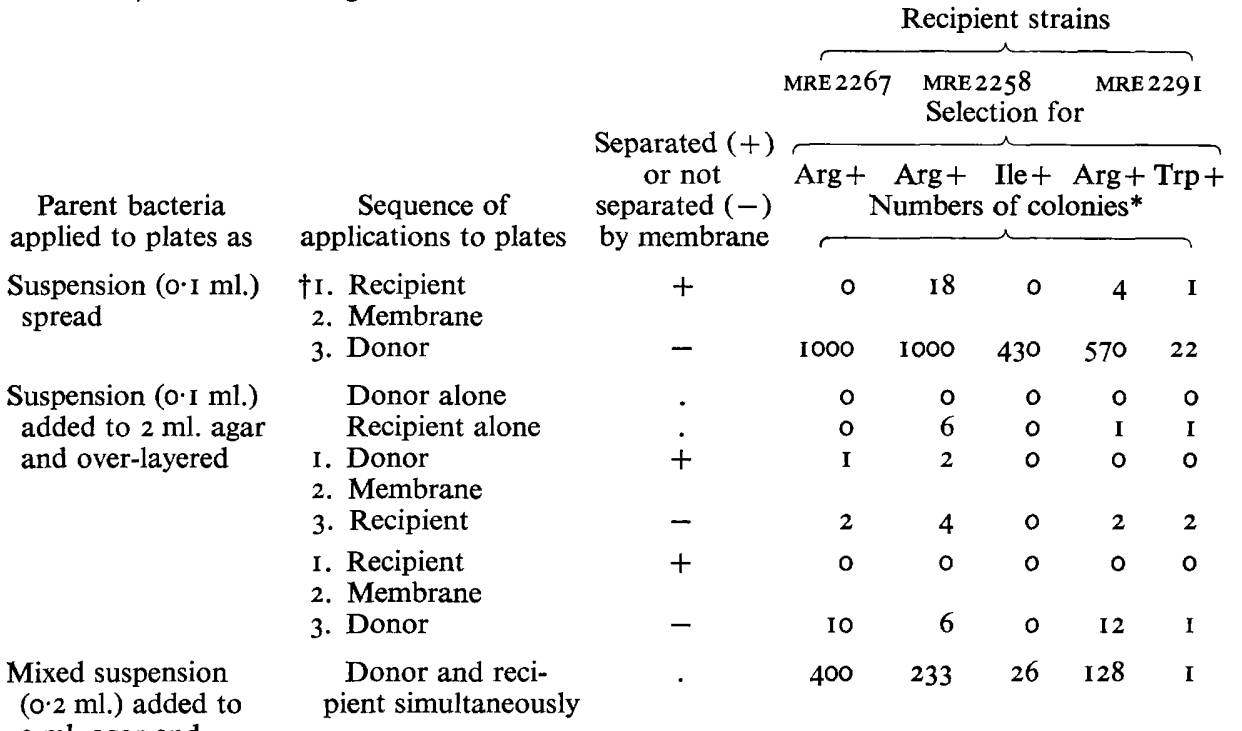

$2 \mathrm{ml}$. agar and

over-layered

* Sums of colonies on duplicated half-plate areas. On membrane-covered half-plate areas colonies growing under and on the membranes are summed; they were stained deep red, to permit counting, by allowing I ml. triphenyltetrazolium chloride solution $(0.25 \%, \mathrm{w} / \mathrm{v})$ to be absorbed by the membrane, followed by $20 \mathrm{~min}$. incubation at $28^{\circ}$.

+ Similar results were obtained with the reverse sequence. Membranes located above or below parental mixtures in normal crosses did not interfere with fertility.

\section{Preliminary observations on the kinetics of marker transfer}

Male specific phage $\mu 2$ (Dettori, Maccacaro \& Piccinin, 196I) formed plaques on lawns of the donor strain but not on those of recipient strains, suggesting that it could be used selectively to eliminate the donor parent from mixtures with recipients. When parental mixtures were incubated in TMB for periods of $10 \mathrm{~min}$. to $7 \mathrm{hr}$ and then treated with phage before plating on selective media no recombinants were obtained. This result suggested either that gene transfer had not occurred in broth during the period (as earlier concluded) or that recombinants were sensitive to phage and were eliminated. Because of the failure to obtain gene transfer in broth, attempts were made to time the entry of the marker arg in crosses conducted on membranes (Matney \& Achenbach, I962). Donor and recipient (MRE 2205) suspensions prepared as for use in crosses were applied to membranes placed on selective medium plates and incubated at $28^{\circ}$. At intervals thereafter membranes were removed, the attached 
organisms suspended in broth, the suspensions violently agitated using a vibrating mixer and divided into two. One half of the vibrated suspension was treated with phage for $20 \mathrm{~min}$ at $37^{\circ}$, the other untreated and both replated on selective medium. Recombinants appeared on untreated suspensions with all samples; they first appeared in phage treated samples after $\mathrm{I} 6 \mathrm{hr}$ had elapsed from the time of applying the mixtures to membranes. After $24 \mathrm{hr}$ treated and untreated samples yielded similar numbers of recombinants. It would seem therefore that many recombinants could survive phage treatment and that arg transfer and expression required a minimum of $\mathrm{I} 6 \mathrm{hr}$ contact of parent strains under the conditions of the experiment.

\section{DISCUSSION}

We conclude from the experiments reported here that gene transfer occurred between strains of Pasteurella pseudotuberculosis. Some alternative explanations for the development of colonies on selective media, which we regard as recombinants, were not substantiated by experiment. It seemed most unlikely that syntrophism of parental mixtures leading to multiple reversions had given a false impression of fertility. First, cross plates did not show the heavy background growth indicative of syntrophism; secondly, permitting increased recipient populations by providing the growth factor for which selection was made, did not result in numbers of revertants approaching the numbers of recombinants obtained in crosses; thirdly, replacement of the donor by an F-Lac- derivative, which would be expected to cross-feed the recipient equally well, resulted in infertility; fourthly, separation of parents by a membrane greatly reduced fertility; and lastly, a large number of recombinants showed unselected donor markers.

Multiple reversions in the recipient strain to give the false impression that donor markers had been acquired seemed equally improbable. Spontaneous revertants subjected to the purification and replication treatment applied to recombinants showed no alteration in other properties for which they were tested. The relative ease with which recombinants appeared with double marker selection for arg trp and the fact that $95 \%$ of these were His + is not explicable on a spontaneous mutation basis. The spontaneous mutation frequencies of the arg-8 and trp-3 loci were both about $\mathrm{I} \times 1 \mathrm{I}^{-8}$ and that for his-8 considerably lower (none have yet been observed). The probability of obtaining triple reversions spontaneously would thus be less than I $\times$ IO $^{-24}$. Similarly recombinants could not have been revertants of the donor strain which carried the non-revertable $p t h-I$ locus, nor mixed clones of donor and recipient since no recombinants showed the donor marker str-II.

The apparent need for firm contact between parent bacteria for the production of recombinants and the inheritance of several donor markers indicate that gene transfer in Pasteurella pseudotuberculosis occurs by a process analogous to that mediated by $\mathrm{F}^{\prime}$ lac in Escherichia coli and involving cell conjugation (Jacob \& Adelberg, 1959). While there is at present no reason to doubt that the mechanisms of gene transfer would be similar in principle in the two genera we would expect to find differences in detail and to meet a number of puzzling situations at this early stage of studies with $P$. pseudotuberculosis. Thus, we failed to obtain recombinants in crosses with Met-, Nic-, Ura - or Thi - recipients. Possibly this means that the loci involved are terminal markers (as str-I I appears to be) and rarely transferred by our donor or excluded by 
lethal zygosis, or they may be closely linked to contraselected donor markers, or $P$. pseudotuberculosis may have more than one linkage group. Again, we have not yet succeeded in obtaining transfer in broth cultures. Possibly this indicates that unions between mating pairs are more fragile than those of $E$. coli or do not form except under conditions where movement of bacteria is restricted, as when held on agar surfaces or membranes. It is puzzling that gene transfer takes some $\mathrm{I} 6 \mathrm{hr}$ under our conditions; does this mean that it is a slow process or do parent bacteria require this time to become competent to mate? Probably with further experience and improvements in technique these and other peculiarities of our system will be resolved. Meanwhile, however, departure from the behaviour shown by fertile systems in $E$. coli cannot be held as evidence against the occurrence of gene transfer in $P$. pseudotuberculosis.

A variable number of recombinants accepted lac in addition to the selected marker. $\mathrm{Lac}+$ recombinants varied in the stability of this property and spontaneously produced Lac - sectors, or clones, with different frequencies. The Lac- segregants however showed no loss of their other selected and unselected donor markers which thus were stably inherited (Morris \& Burrows, in preparation). We infer that Lac+ recombinants carry an integrated fragment of the donor chromosome and an autonomous $\mathrm{F}^{\prime}$ lac plasmid.

The base composition of DNA extracted from our donor strain of Pasteurella pseudotuberculosis (determined by W.D.L. using the method of Marmur \& Doty, I962) was $45.6 \% \mathrm{G}+\mathrm{C}\left(\mathrm{T}_{\mathrm{m}} 88.0\right)$, and that from Escherichia coli strain 23.10s, determined in the same experiment, was $50 \% \mathrm{G}+\mathrm{C}\left(\mathrm{T}_{\mathrm{m}} 89.8\right)$. This $4.4 \%$ difference is noteworthy since donor chromosome mobilization by the $\mathrm{F}$ factor had not been observed in bacteria that differed in base composition from $E$. coli by more than $\mathrm{r} \% \mathrm{G}+\mathrm{C}$ (S. Falkow, personal communication). However, we know from geldiffusion analyses (unpublished) that Pasteurella and Escherichia show at least three common antigens, they have some common phage sensitivities (Stocker, I955; Smith \& Burrows, 1962; Hertman, 1964) and show close taxonomic relationships in classifications based on Adansonian principles (Sneath \& Cowan, 1958). The availability of a fertility system in $P$. pseudotuberculosis should eventually permit the construction of a chromosome map for this species and allow comparison with those of $E$. coli (Taylor \& Thoman, 1964) and Salmonella typhimurium (Sanderson \& Demerec, I965).

Two other interesting problems would now seem to be amenable to investigation. Genetic studies on bacterial virulence have been initiated in strains of Shigella flexneri (Falkow, Schneider, Baron \& Formal, 1963) and Salmonella typhimurium (Krishnapillai \& Baron, 1964). The accumulated knowledge of factors determining virulence in Pasteurella, (Burrows, 1963) coupled with the ability to promote gene transfer in this genus should provide an excellent system for fruitful studies of the important property of virulence. Secondly, genetic studies should permit an assessment of the validity of claims for the inter-conversion of Pasteurella pestis and $P$. pseudotuberculosis, made by several investigators but never using genetically marked strains, nor in an entirely convincing manner (see discussion by Brubaker, Surgalla \& Beesley, 1965). In recent experiments we have shown that crosses between $P$. pseudotuberculosis and $P$. pestis are fertile; there would therefore appear to be no impediment to a future decision on the interconvertibility of the two species. 
It is a pleasure to acknowledge the contribution to our early studies by $\mathrm{Mr} \mathrm{J}$. Boyle and the excellent technical assistance of Mr P. E. Stone throughout this work. This study was mainly conducted during a one-year visit of W.D.L. to the Microbiological Research Establishment.

\section{REFERENCES}

Brubaker, R. R., Surgalla, M. J. \& Beesley, E. D. (1965). Pesticinogeny and bacterial virulence. Zentbl. Bakt. (I. Abt. Orig.) 196, 302.

Burrows, T. W. (1962). Genetics of virulence in bacteria. Br. med. Bull. 18, 69.

BurRows, T. W. (1963). Virulence of Pasteurella pestis and immunity to plague. Ergebn. Mikrobiol. ImmunForsch. exp. Ther. 37, 59.

Demerec, M., Adelberg, E. A., Clark, A. J. \& Hartman, P. E. (1966). A proposal for a uniform nomenclature in bacterial genetics. Genetics 54,61 .

Dettori, R., Maccacaro, G. A. \& Piccinin, G. L. (I961). Sex-specific bacteriophages of Escherichia coli $\mathrm{K}$ I2. G. Microbiol. 9, I4I.

Dushman, M. B. (1963). Origin of prototrophic variants in mixtures of auxotrophic mutants of Serratia marcescens. J. Bact. 86, 1173.

Falkow, S., Schneider, H., Baron, L. S. \& Formal, S. (1963). Virulence of Escherichia-Shigella genetic hybrids for the guinea pig. J. Bact. 86, 125I.

HAYES, W. (1953). The mechanism of genetic recombination in Escherichia coli. Cold Spring Harbor Symp. quant. Biol. 18, 75.

Hertman, I. (1964). Bacteriophage common to Pasteurella pestis and Escherichia coli. J. Bact. 88, I002.

JACOB, F. \& Adelberg, E. A. (1959). Transfert de caractères génétiques par incorporation au facteur sexuel d'Escherichia coli. C. r. hebd. Séanc. Acad. Sci., Paris 249, 189.

KAUDEWITZ, F. (1959). Production of bacterial mutants with nitrous acid. Nature, Lond. 183, 1829.

KRISHNAPILlaI, V. \& BARON, L.S. (1964). Alterations in the mouse virulence of Salmonella typhimurium by genetic recombination. J. Bact. 87, 598.

MARMUR, J. \& DoTY, P. (I962). Determination of the base composition of deoxyribonucleic acid from its thermal denaturation temperature. J. molec. Biol. 5, 109.

Martin, G. \& JACOB, F. (I962). Transfert de l'épisome sexuel d'Escherichia coli à Pasteurella pestis. C. r. hebd. Séanc. Acad. Sci., Paris 254, 3589.

MAtNEY, T. S. \& ACHENBACH, N. E. (I962). New uses for membrane filters. III. Bacterial mating procedure. J. Bact. 84, 875 .

SANDERSON, K. E. \& DemereC, M. (1965). The linkage map of Salmonella typhimurium. Genetics 51, 897.

SMITH, D. A. \& Burrows, T. W. (1962). Phage and bacteriocin investigations with Pasteurella pestis and other bacteria. Nature, Lond. 193, 397.

SNEATH, P. H. A. \& CoWAN, S. T. (1958). An electro-taxonomic survey of bacteria. J. gen. Microbiol. I9, 55 I.

STAMP, LORD (1947). The preservation of bacteria by drying. J. gen. Microbiol. r, $25 \mathrm{I}$.

STOCKER, B. A. D. (1955). Bacteriophage and bacterial classification. J. gen. Microbiol. 12, 375.

TAYLOR, A. L. \& THOMAN, M. S. (1964). The genetic map of Escherichia coli K I2. Genetics 50, 659. 